\title{
Nitrite Intoxication of Common Carp (Cyprinus carpio L.) at Different Water Temperatures
}

\author{
H. KROUPOVÁ ${ }^{1}$, J. MÁCHOVÁ ${ }^{1}$, V. PIAČKOVÁ ${ }^{1}$, M. FLAJŠHANS ${ }^{1}$, Z. SVOBODOVÁ ${ }^{1,2}$, \\ G. POLESZCZUK ${ }^{3}$ \\ ${ }^{1}$ University of South Bohemia České Budějovice, Research Institute of Fish Culture and Hydrobiology, \\ Vodňany, Czech Republic \\ ${ }^{2}$ University of Veterinary and Pharmaceutical Sciences, Brno, Czech Republic \\ ${ }^{3}$ Szczecin University, Szczecin, Poland \\ Received March 6, 2006 \\ Accepted June 30, 2006
}

\begin{abstract}
Kroupová H., J. Máchová, V. Piačková, M. Flajšhans, Z. Svobodová, G. Poleszczuk: Nitrite Intoxication of Common Carp (Cyprinus carpio L.) at Different Water Temperatures. Acta Vet Brno 2006, 75: 561-569.

Common carp (Cyprinus carpio L.) were exposed to nitrite $\left(1.45 \mathrm{mmol} \cdot \mathrm{l}^{-1} \mathrm{NO}_{2}{ }^{-}\right)$for 48 hours at $14{ }^{\circ} \mathrm{C}$ and $20{ }^{\circ} \mathrm{C}$, in order to investigate the mechanism of nitrite poisoning at these water temperatures. The effect of nitrite exposure on fish was assessed on selected haematological and biochemical indicators of the blood. Moreover, nitrite accumulation in the blood, liver and muscle was measured. Nitrite exposure produced high levels of methaemoglobin $(88.2 \pm 3.3 \%$ and 92.9 $\pm 6.1 \%)$ at both water temperatures compared with controls $(0.3 \pm 0.6 \%$ and $2.6 \pm 3.0 \%)$. High fish mortality occurred in experimental groups (30\% and $51 \%)$ compared with controls $(0 \%)$. Nitrite exposure also resulted in an accumulation of nitrite in the fish body. The highest nitrite levels developed in the blood plasma, followed by the liver and muscle, respectively. Carp concentrated nitrite in the blood plasma and tissues to markedly higher levels at higher temperature $\left(20^{\circ} \mathrm{C}\right)$. The plasma nitrite concentrations $\left(10.5 \pm 1.9 \mathrm{mmol}^{-1} \mathrm{l}^{-1}\right)$ were in this case more than 7 times higher than the environmental one. At lower temperature $\left(14{ }^{\circ} \mathrm{C}\right)$, plasma nitrite concentration reached $5.0 \pm 1.5 \mathrm{mmol} \cdot \mathrm{l}^{-1}$. In either event, plasma $\mathrm{K}^{+}$levels increased and $\mathrm{Cl}^{-}$levels and osmolality remained unchanged. Plasma $\mathrm{Na}^{+}$levels slightly decreased at the higher temperature. Nitriteexposed fish showed lower haematocrit values (PCV) at both experimental temperatures compared with controls. At $20^{\circ} \mathrm{C}$, the blood haematocrit decrease $\left(0.20 \pm 0.021 \cdot 1^{-1}\right)$ was accompanied by a low erythrocyte count $\left(1.05 \pm 0.12 \cdot 10^{12} \mathrm{l}^{-1}\right)$ and by a low haemoglobin level $\left(51 \pm 11 \mathrm{~g} \cdot \mathrm{l}^{-1}\right)$. At the lower temperature $\left(14{ }^{\circ} \mathrm{C}\right)$, the haematocrit decrease $\left(0.25 \pm 0.021 \cdot l^{-1}\right)$ was caused by a low mean corpuscular volume $(167 \pm 27 \mathrm{fl})$. No significant changes were observed in the mean corpuscular haemoglobin $(\mathrm{MCH})$, mean corpuscular haemoglobin concentration (MCHC), or selected erythrocyte dimensions (major axis, minor axis and aspect ratio).
\end{abstract}

Fish, nitrite accumulation, haematology, biochemical indices, methaemoglobinaemia

An intensive culture of several fish species in recirculation systems has become very popular in Europe during the last few decades. This kind of aquaculture relies on recirculating water systems that remove waste ammonia from water. Ammonia, i.e. the main product of protein metabolism of fish (Wood 1993), is removed from the tanks by nitrification (conversion to nitrites and subsequently to nitrates) by means of bio-filters. Imbalance in the nitrification process can often lead to an increase in the nitrite concentrations by up to $1 \mathrm{mmol} \cdot \mathrm{l}^{-1} \mathrm{NO}_{2}^{-}$or more (Kamstra et al. 1996). This may result in mass fish mortality ( $\mathrm{S} v$ obodová et al. 2005a).

Nitrite is actively taken up through the gills and enters the blood stream (Margiocco et al. 1983; Jen sen et al. 1987). From the blood plasma, nitrite diffuses into red blood cells, where it oxidises the iron in haemoglobin to the +3 oxidation state to produce methaemoglobin, which lacks the capacity to bind oxygen (Bodansky 1951). Methaemoglobin turns the blood to a chocolate-brown colour. So, nitrite poisoning is

Address for correspondence:

Hana Kroupová

University of South Bohemia

Research Institute of Fish Culture and Hydrobiology

Zátiší 728/II, 38925 Vodňany, Czech Republic

Phone: +420383382402

Fax: +420383 382396

E-mail: kroupova@vurh.jcu.cz

http://www.vfu.cz/acta-vet/actavet.htm 
sometimes called a brown blood disease. However, recent studies on fish have discovered that nitrite is a disrupter of multiple physiological functions and that the toxicity of nitrite results from a combination of effects rather than from any single effect in particular (J en s e n 2003).

Nitrite toxicity in fish depends on a large number of external and internal factors. Among the most important ones is water quality, especially the chloride concentration in water (Crawford and Allen 1977; Lewis and Morris 1986; Svobodová et al. 2005b; Pištěková et al. 2005). However, little is known about the influence of temperature on nitrite toxicity. Only a few reports have appeared on this topic and a definite conclusion has not been reached (Colt and Tchobanoglous 1976; Huey et al. 1984). Generally, the water temperature is an important factor that determines chemical toxicity (Cairns et al. 1975) and it has multiple effects on both water characteristics and fish physiology. Therefore, the aim of our study was to discover the influence of water temperature on the nitrite toxicity mechanism in common carp (Cyprinus carpio L.). The effect of nitrite exposure on fish at different temperatures was assessed on selected haematological and biochemical indicators of the blood. Moreover, nitrite accumulation in the blood and in selected tissues was measured.

\section{Materials and Methods}

Experimental animals

Common carp (Cyprinus carpio L.; weight $280 \pm 52 \mathrm{~g}$, mean \pm SD) were obtained from a local fish hatchery and maintained for 2 weeks in aquaria with dechlorinated tap water. Four days before the start of the experiment, the fish were divided into four groups and acclimated to $14{ }^{\circ} \mathrm{C}$ and $20^{\circ} \mathrm{C}$. Temperatures between $14-20{ }^{\circ} \mathrm{C}$ prevail during the growing season (4 - 5 months) in the Czech Republic. During acclimation and experimental period, the fish were not fed.

Experimental protocol and fish sampling

The test was performed in a semistatic assay for $48 \mathrm{~h}$. Fish were kept in tanks each containing 2001 of test solution. During the acclimation and experimental period, the basic chemical indices of water were as follows: $\mathrm{ANC}_{4.5}$ (acid neutralisation capacity) $1.15 \mathrm{mmol} \cdot \mathrm{l}^{-1}$; $\mathrm{COD}_{\mathrm{Mn}}$ (chemical oxygen demand) $1.5 \mathrm{mg} \cdot \mathrm{l}^{-1}$; total ammonia $0.04 \mathrm{mg} \cdot \mathrm{l}^{-1} ; \mathrm{NO}_{3}{ }^{-} 7.8 \mathrm{mg} \cdot \mathrm{l}^{-1} ; \mathrm{PO}_{4}{ }^{3-} 0.01 \mathrm{mg} \cdot \mathrm{l}^{-1}$; sum of $\mathrm{Ca}^{2+}+\mathrm{Mg}^{2+} 14 \mathrm{mg} \cdot \mathrm{l}^{-1}, \mathrm{Cl}^{-} 11 \mathrm{mg} \cdot \mathrm{l}^{-1}$. Oxygen saturation of the water ranged from 81 to $92 \%$ and the $\mathrm{pH}$ ranged from 7.08 to 7.57 . Four groups each containing 30 specimens of two-year-old carp were exposed to nitrite at different water temperatures $\left(14{ }^{\circ} \mathrm{C}\right.$ and $\left.20^{\circ} \mathrm{C}\right)$ :

Group E1:

Group C1 (control 1):

Group E2:

Group C2 (control 2):

$$
1.45 \mathrm{mmol} \cdot 1^{-1}\left(67 \mathrm{mg} \cdot 1^{-1}\right) \mathrm{NO}_{2}^{-}, \mathrm{t}=14.2 \pm 0.2^{\circ} \mathrm{C}
$$

traces $\mathrm{NO}_{2}^{-} ; \mathrm{t}=14.2 \pm 0.2{ }^{\circ} \mathrm{C}^{-1}$

$1.45 \mathrm{mmol} \cdot \mathrm{l}^{-1}\left(67 \mathrm{mg} \cdot \mathrm{l}^{-1}\right) \mathrm{NO}_{2}^{-}, \mathrm{t}=20.6 \pm 0.5^{\circ} \mathrm{C}$

traces $\mathrm{NO}_{2}^{-} ; \mathrm{t}=20.6 \pm 0.5^{\circ} \mathrm{C}$

The nitrite concentration was obtained by adding $\mathrm{NaNO}_{2}$ to dechlorinated tap water. The dose of environmental nitrite represented the median lethal concentration for common carp at a similar chloride water concentration (Máchová and Svobodová 2001). Nitrite and chloride content was checked twice during the test and measured values did not differ from the nominal value by more than 10 percent.

A total of 28 carp ( 7 from each group) was examined to determine the haematological and biochemical profiles of blood. The blood samples were taken from the heart after 48 hour of nitrite exposure. The blood was stabilised by $40 \mathrm{IU}$ of sodium heparin per $1 \mathrm{ml}$ blood. The erythrocyte count (RBC), haematocrit (PCV), haemoglobin $(\mathrm{Hb})$, methaemoglobin (MetHb), mean corpuscular volume (MCV), mean corpuscular haemoglobin (MCH), and the mean corpuscular haemoglobin concentration (MCHC) were determined in the blood samples ( S v ob od ová et al. 1991). To measure the dimensions of native erythrocytes, $5 \mu$ of native blood of each fish analysed was pipetted into $1 \mathrm{ml}$ of isotonic physiological saline (osmolality $289 \pm 5 \mathrm{mmol} \cdot \mathrm{kg}^{-1}$ ). The sample was gently vortexed and $20 \mu \mathrm{l}$ was immediately pipetted on to a clean microscopic slide. No coverslip was used because drift of cells in the sample would make difficult the precise scoring of cells in captured images. The slide was placed on the stage of an Olympus BHS microscope of which the focus level had been pre-adjusted to the slide surface. Erythrocytes sedimented on the slide surface were recorded with a 3CCD Sony DXC-9100P colour camera coupled to the microscope, and processed by the Olympus MicroImage v. 4.0 software in order to measure erythrocyte major and minor axes, and to compute the aspect ratio (relationship between horizontal and vertical axes).

Plasma was separated from cells by centrifugation $(10 \mathrm{~min}$ at $12,000 \times g)$ at $4{ }^{\circ} \mathrm{C}$ and plasma $\mathrm{Na}^{+}, \mathrm{K}^{+}$and $\mathrm{Cl}^{-}$, and $\mathrm{NO}_{2}{ }^{-}$concentrations were determined. After blood sampling, the fish were quickly stunned with a blow to the head, and approximately $1 \mathrm{~g}$ pieces of muscle and liver were taken. In these tissues, the nitrite concentration was also measured. The tissue samples were kept at $-80^{\circ} \mathrm{C}$ until analysis to prevent nitrite oxidation. 
Chemical analyses

Nitrite levels in the blood plasma, liver and muscle were determined as described in Shechter et al. (1972). Plasma $\mathrm{Na}^{+}, \mathrm{K}^{+}$and $\mathrm{Cl}^{-}$concentrations were measured by ion-selective electrodes (ADVIA 1650, Bayer). Osmolality of the blood plasma and physiological saline used as a diluent for the measurement of selected erythrocyte proportions was determined using a vapour pressure osmometer (VAPRO 5520, Wescor).

Statistical analysis

Statistical software STATISTICA (version 6.1 for Windows, StatSoft) was used to determine differences between the test groups. At the beginning, all measured variables were checked for normality (KolmogorovSmirnov test) and homoskedasticity of variance (Bartlett's test). If those conditions were satisfied, one-way ANOVA was applied to determine whether there were any significant differences in measured variables between nitrite-exposed fish at different temperatures and control fish. When a difference was detected $(p<0.05)$, Tukey's multiple comparison test was applied. If the conditions for ANOVA were not satisfied, the non-parametric test (Kruskal-Wallis's test) was used.

Contingency tables were applied to determine differences in mortality between test groups (Zar 1996).

\section{Results}

Fish mortality

No mortality was observed in the control groups. High fish mortality was noticed during nitrite poisoning in group E1 (30\%) and E2 (51\%) compared with the control groups. The difference between group E1 and E2 was not statistically significant $\left(\chi^{2}=3.28, \mathrm{df}=1, p=\right.$ $0.07)$.

Nitrite concentration in selected tissues (blood plasma, liver and muscle)

Exposure of carp to $1.45 \mathrm{mmol} \cdot \mathrm{l}^{-1}$ of ambient nitrite resulted in an accumulation of nitrite in the blood plasma to $5.0 \pm 1.5 \mathrm{mmol} \cdot \mathrm{l}^{-1}$ at $14{ }^{\circ} \mathrm{C}$ (group E1) and $10.5 \pm 1.9 \mathrm{mmol} \cdot \mathrm{l}^{-1}$ at $20^{\circ} \mathrm{C}$ (group E2). The nitrite concentration in group E2 was significantly higher $(p<0.05)$ than in group E1 (Fig. 1). The plasma nitrite concentrations were more than 3.5 (group E1) and 7 times (group E2) greater than environmental ones.
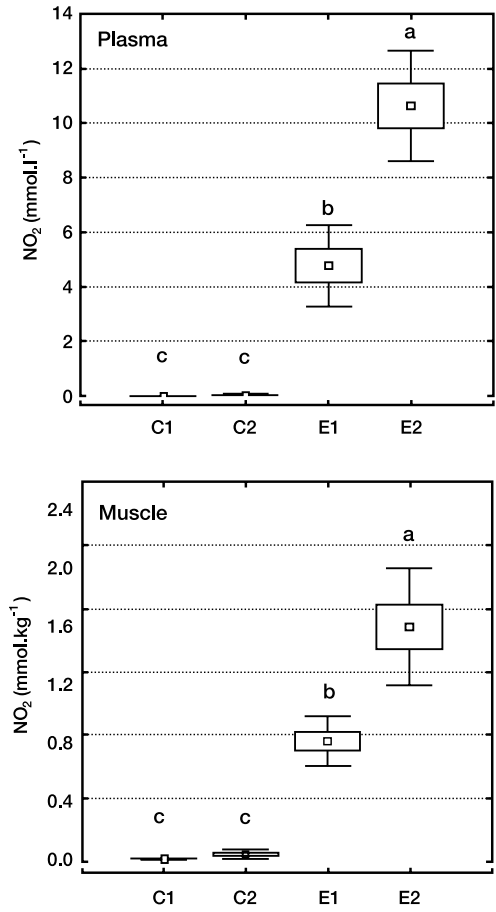

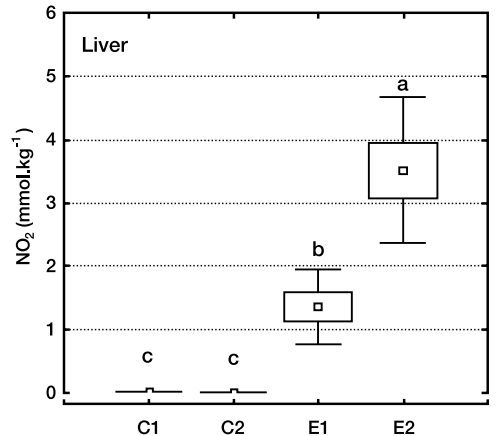

Fig. 1. Nitrite concentrations in the blood plasma, liver and muscle of common carp (Cyprinus carpio L.) exposed to $1.45 \mathrm{mmol}^{-1} \mathrm{l}^{-1}$ during 48 hours at different temperatures. Experimental groups E1 $\left(14^{\circ} \mathrm{C}\right)$ and E2 $\left(20^{\circ} \mathrm{C}\right)$. Control groups $\mathrm{C} 1\left(14{ }^{\circ} \mathrm{C}\right)$ and $\mathrm{C} 2\left(20{ }^{\circ} \mathrm{C}\right)$. Significant differences $(p<0.05)$ are indicated by different letters. ( $\square$ Mean, $\square$ Mean \pm SE, I Mean $\pm \mathrm{SD}$ ). 
Nitrite also accumulated in the muscle and liver of carp, but these tissues showed lower accumulated levels of the toxicant compared with the blood plasma (Fig. 1). The levels of nitrite in the liver in group E1 and E2 were as follows: $1.4 \pm 0.6 \mathrm{mmol} \cdot \mathrm{kg}^{-1}$ and $3.5 \pm 1.1 \mathrm{mmol} \cdot \mathrm{kg}^{-1}$, respectively, and in the muscle $0.76 \pm 0.16 \mathrm{mmol} \cdot \mathrm{kg}^{-1}$ and $1.5 \pm 0.4 \mathrm{mmol} \cdot \mathrm{kg}^{-1}$, respectively. Nitrite levels, both in the liver and in the muscle, were significantly higher $(p<0.05)$ at the higher temperature.

Haematological variables

Nitrite exposure affected the following haematological variables: methaemoglobin and haemoglobin concentrations, haematocrit values, erythrocyte count and mean corpuscular volumes (Fig. 2).

The methaemoglobin content increased markedly $(p<0.01)$ in both experimental groups E1 and E2 $(88.2 \pm 3.3 \%$ and $92.9 \pm 6.1 \%$, respectively) compared with the control groups $(\mathrm{C} 1: 0.3 \pm 0.6 \% ; \mathrm{C} 2: 2.6 \pm 3.0 \%)$ (Fig. 2). The haematocrit values (Fig. 2) were significantly lower $(p<0.01)$ in the carp of group E1 $\left(0.25 \pm 0.021 \cdot 1^{-1}\right)$ compared with control group C1 $\left(0.33 \pm 0.041 \cdot 1^{-1}\right)$ and values in the carp of group E2 $\left(0.20 \pm 0.021 \cdot 1^{-1}\right)$ were significantly lower compared with control group C2 $\left(0.31 \pm 0.031 \cdot 1^{-1}\right)$. The haematocrit values were significantly lower in group E2 compared with group E1. The erythrocyte counts decreased significantly $(p<0.01)$ only in group E2 $\left(1.05 \pm 0.12 \cdot 10^{12} \mathrm{l}^{-1}\right)$ (Fig. 2). In group E1, the erythrocyte counts $\left(1.56 \pm 0.21 \cdot 10^{12} \mathrm{l}^{-1}\right)$ did not differ significantly from the control groups $\left(\mathrm{C} 1: 1.70 \pm 0.20 \cdot 10^{12} \mathrm{l}^{-1}\right.$; C2: $\left.1.54 \pm 0.24 \cdot 10^{12} \mathrm{l}^{-1}\right)$. In group E2, a markedly lower haemoglobin concentration $\left(51 \pm 11 \mathrm{~g} \cdot \mathrm{l}^{-1}, p<0.01\right)$ was found compared with groups E1 (75 $\left.\pm 5 \mathrm{~g} \cdot \mathrm{l}^{-1}\right), \mathrm{C} 1\left(84 \pm 9 \mathrm{~g} \cdot \mathrm{l}^{-1}\right)$, and C2 $\left(76 \pm 10 \mathrm{~g} \cdot \mathrm{l}^{-1}\right)$ (Fig. 2). Significantly lower $(p<0.05)$ MCV values were found in carp of groups E1 (167 $\pm 27 \mathrm{fl})$ compared with groups E2 (190 $\pm 25 \mathrm{fl}), \mathrm{C} 1(195 \pm 24 \mathrm{fl})$, and C2 (195 $\pm 16 \mathrm{fl})$ (Fig. 2). No significant changes were observed in the $\mathrm{MCH}$ and MCHC. No significant differences were also found in selected erythrocyte proportions: major axis $(\mathrm{C} 1: 13.4 \pm 1.0 \mu \mathrm{m} ; \mathrm{C} 2: 14.2 \pm 0.4 \mu \mathrm{m} ; \mathrm{E} 1: 13.8 \pm 1.1 \mu \mathrm{m} ; \mathrm{E} 2: 14.1 \pm 0.5$ $\mu \mathrm{m})$, minor axis (C1: $9.3 \pm 0.8 \mu \mathrm{m}$; C2: $10.5 \pm 0.3 \mu \mathrm{m}$; E1: $9.6 \pm 0.9 \mu \mathrm{m}$; E2: $10.4 \pm 0.6 \mu \mathrm{m})$, and aspect ratio $(\mathrm{C} 1: 1.5 \pm 0.2 \mu \mathrm{m} ; \mathrm{C} 2: 1.4 \pm 0.1 \mu \mathrm{m}$; E1: $1.4 \pm 0.2 \mu \mathrm{m}$; E2: $1.4 \pm 0.1 \mu \mathrm{m})$.

Concentration of plasma $\mathrm{K}^{+}, \mathrm{Na}^{+}, \mathrm{Cl}^{-}$and plasma osmolality

Major changes were observed in plasma $\mathrm{K}^{+}$values (Fig. 3). Significant differences $(p<0.05)$ were found among all of the test groups. In the carp of group E1, nitrite exposure caused a significant $(p<0.01)$ increase of $121 \%$ in the plasma $\mathrm{K}^{+}$concentration compared with control group C1. In the carp of group E2, an increase $(p<0.01)$ of $112 \%$ compared with control group $\mathrm{C} 2$ was observed. However, we also observed a significant difference between control groups C1 $\left(2.2 \pm 0.60 \mathrm{mmol} \cdot \mathrm{l}^{-1}\right)$ and C2 $\left(1.8 \pm 0.39 \mathrm{mmol} \cdot \mathrm{l}^{-1}\right)$.

A slight (only $5 \%$ ) but significant $(p<0.05)$ decrease in plasma $\mathrm{Na}^{+}$values was observed in group E2 compared with the control (group C2) (Fig. 3). No statistically significant differences were observed in the plasma $\mathrm{Na}^{+}$concentration at the lower temperature. However, a significant $(p<0.01)$ difference was found between control groups $\mathrm{C} 1$ and $\mathrm{C} 2$. No statistically significant differences were observed in plasma $\mathrm{Cl}^{-}$concentrations among all of the test groups (Fig. 3). Finally, no significant differences were observed in plasma osmolality $\left(\mathrm{C} 1: 287 \pm 7 \mathrm{mmol} \cdot \mathrm{kg}^{-1}, \mathrm{C} 2: 287 \pm 6 \mathrm{mmol} \cdot \mathrm{kg}^{-1}, \mathrm{E} 1: 286 \pm 7 \mathrm{mmol} \cdot \mathrm{kg}^{-1}, \mathrm{E} 2: 287\right.$ $\left.\pm 5 \mathrm{mmol} \cdot \mathrm{kg}^{-1}\right)$.

\section{Discussion}

High fish mortality was observed during nitrite poisoning at both $14{ }^{\circ} \mathrm{C}$ (group E1 mortality $30 \%$ ) and $20^{\circ} \mathrm{C}$ (group E2 - mortality 51\%). However, no significant influence of temperature on mortality in common carp was found.

Nitrite exposure of common carp resulted in nitrite accumulation in the fish body. The 

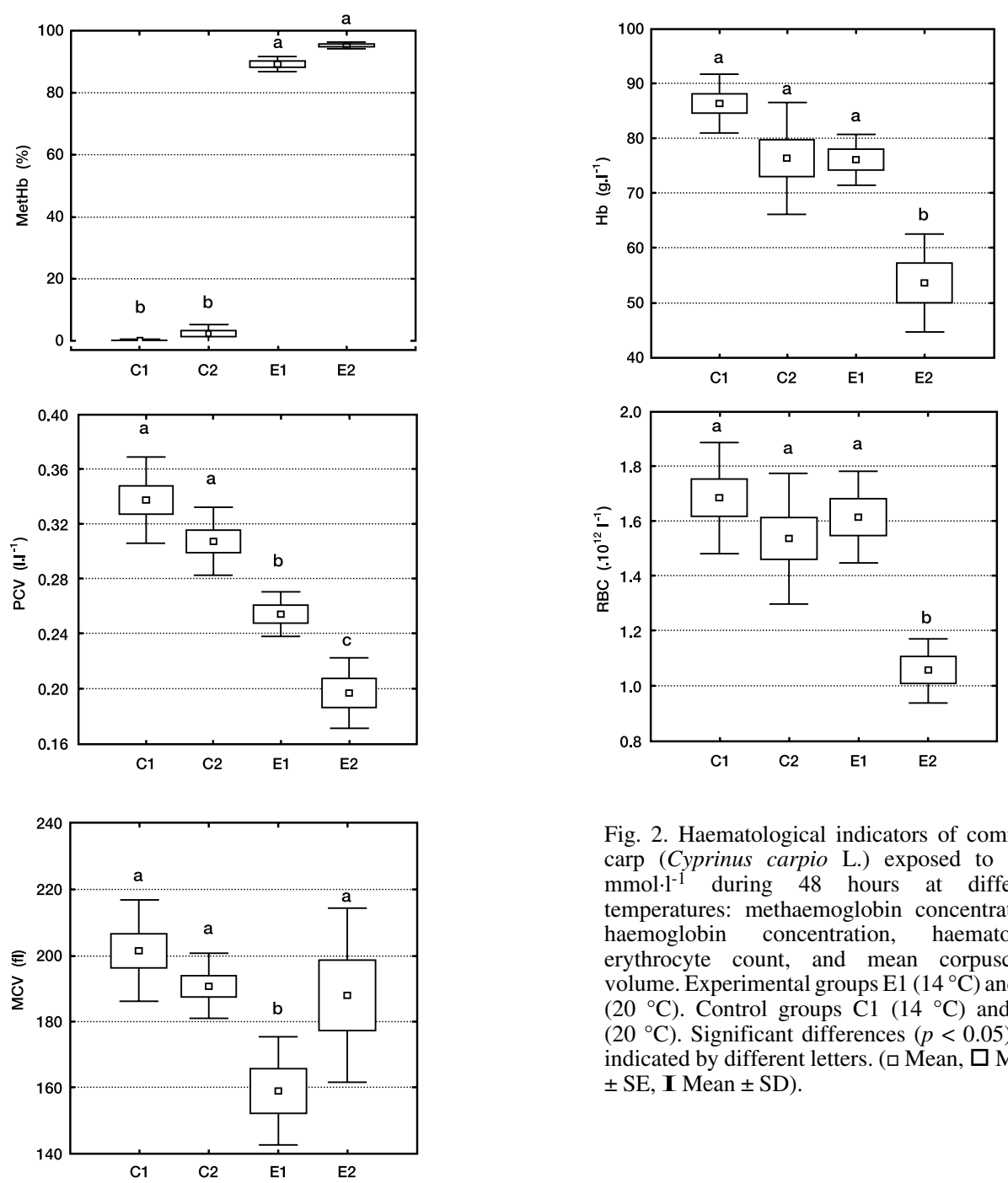

Fig. 2. Haematological indicators of common carp (Cyprinus carpio L.) exposed to 1.45 mmol. $1^{-1}$ during 48 hours at different temperatures: methaemoglobin concentration, haemoglobin concentration, haematocrit, erythrocyte count, and mean corpuscular volume. Experimental groups E1 $\left(14^{\circ} \mathrm{C}\right)$ and E2 $\left(20^{\circ} \mathrm{C}\right)$. Control groups $\mathrm{C} 1\left(14{ }^{\circ} \mathrm{C}\right)$ and $\mathrm{C} 2$ $\left(20{ }^{\circ} \mathrm{C}\right)$. Significant differences $(p<0.05)$ are indicated by different letters. ( $\square$ Mean, $\square$ Mean $\pm \mathrm{SE}$, I Mean $\pm \mathrm{SD}$ )

highest nitrite levels developed in the blood plasma, followed by the liver and muscle, respectively. Similar results were found by Margiocco et al. (1983) in rainbow trout (Oncorhynchus mykiss, Walbaum), showing that relatively low nitrite values developed in the muscle and high nitrite concentrations developed in the liver, brain, and gills. On the other hand Gisbert et al. (2004) observed a higher nitrite content in the skeletal musculature than in the blood plasma of Siberian sturgeon (Acipenser baerii, Brandt). In our experiment, plasma nitrite concentrations reached $5.0 \mathrm{mmol} \cdot \mathrm{l}^{-1}$ and $10.5 \mathrm{mmol} \cdot \mathrm{l}^{-1}$ at $14^{\circ} \mathrm{C}$ and $20^{\circ} \mathrm{C}$, respectively. This represents a concentration 3.5 times, respectively 7 times higher than in the surrounding medium. It is well in line with the revealed results of Jen sen et al. (1987) on common carp. In this case, exposing carp to $1 \mathrm{mmol} \cdot \mathrm{l}^{-1}$ of nitrite for 24 hours resulted in increased blood plasma nitrite to $3.2 \mathrm{mmol} \cdot \mathrm{l}^{-1}$ at $15^{\circ} \mathrm{C}$. Our results also suggest that nitrite accumulated to significantly higher levels at higher temperature in both the blood 

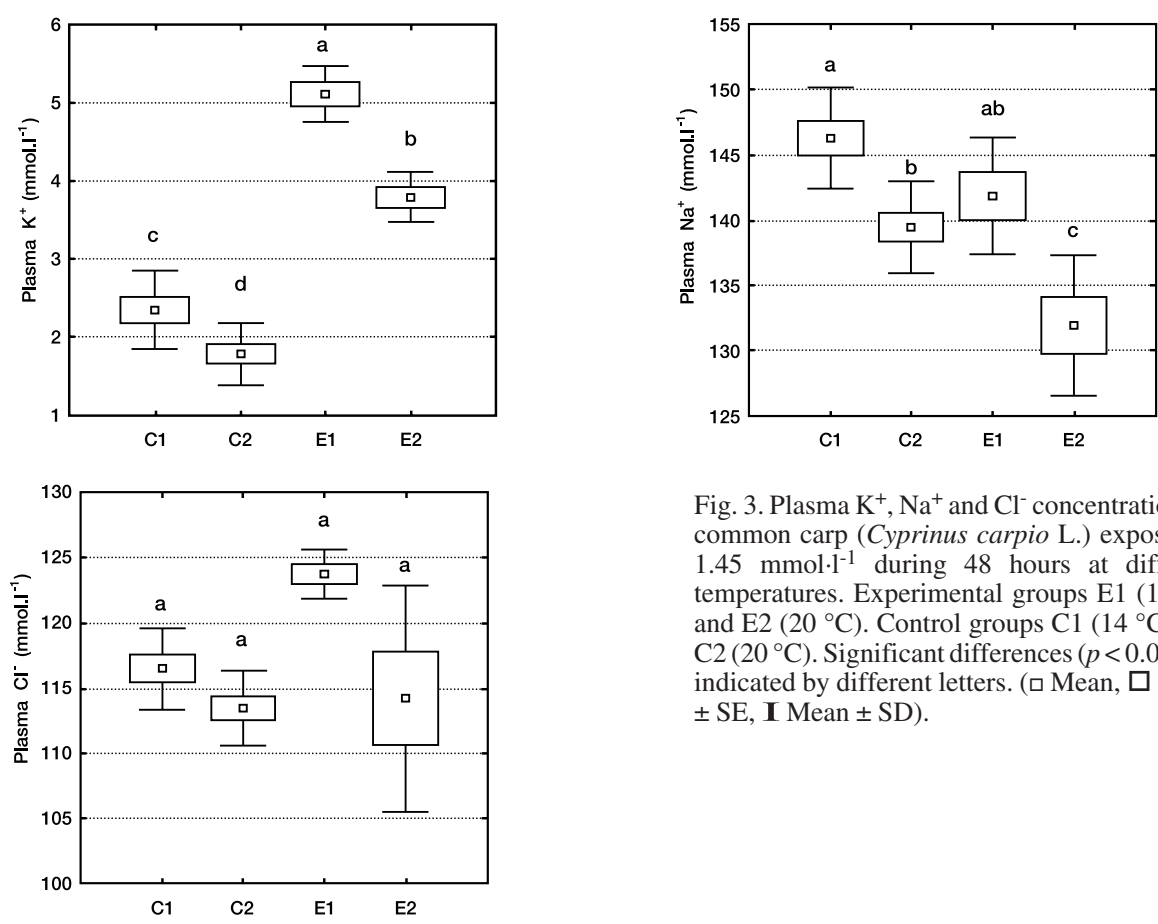

Fig. 3. Plasma $\mathrm{K}^{+}, \mathrm{Na}^{+}$and $\mathrm{Cl}^{-}$concentrations in common carp (Cyprinus carpio L.) exposed to $1.45 \mathrm{mmol} \cdot \mathrm{l}^{-1}$ during 48 hours at different temperatures. Experimental groups E1 $\left(14{ }^{\circ} \mathrm{C}\right)$ and E2 $\left(20^{\circ} \mathrm{C}\right)$. Control groups $\mathrm{C} 1\left(14^{\circ} \mathrm{C}\right)$ and $\mathrm{C} 2\left(20^{\circ} \mathrm{C}\right)$. Significant differences $(p<0.05)$ are indicated by different letters. ( $\square$ Mean, $\square$ Mean $\pm \mathrm{SE}$, I Mean $\pm \mathrm{SD}$ ).

plasma and in selected tissues of the carp. Information on the influence of temperature on nitrite accumulation in fish is limited, but in crayfish (Astacus asctacus L.) a lowering of temperature significantly slows down nitrite accumulation (Jeberg and Jensen 1994). Since fish and crayfish are poikilothermic, their physiological processes are highly affected by environmental temperature. This means that the metabolic rate, heart rate, enzyme activities, and blood flow accelerate as body temperature increases and slow down at colder body temperature. For example, Metz et al. (2003) observed a temperature-enhanced branchial enzymatic pump activity in common carp. In our experiment, increasing temperature probably also affected the activity of enzymes involved in the ion uptake through the gills, subsequently causing faster nitrite accumulation in the blood plasma and tissues of carp. Furthermore, chloride cell proliferation may by another factor contributing to higher nitrite accumulation at higher temperature (Schmidt et al. 1998).

As predicted, exposure of carp to nitrite caused a significant increase in methaemoglobin levels. Nitrite-treated carp also showed typical symptoms of methaemoglobinaemia, manifested by unresponsive and disoriented behaviour, and brown colouring of the blood and gills. In our experiment, high metHb levels in the blood of both experimental groups were well in accordance with high nitrite concentrations in the water. MetHb content reached approximately $90 \%$ of functional haemoglobin. Such value is highly critical for fish survival (Lew is and Morris 1986). Although there were higher nitrite levels in the plasma of fish at $20^{\circ} \mathrm{C}$, the fish continued to live even in those conditions. Also, metHb levels were nearly the same as at the lower temperature. This may be explained by varied efficiency of the methaemoglobin reductase enzyme at different temperatures. The red blood cells of fish contain NADH-methaemoglobin reductase that reconverts methaemoglobin to haemoglobin (Cameron 1971). This occurs steadily and will restore the normal proportion of haemoglobin within 24 - 72 hours if a fish is transferred to water that lacks nitrite (Hu ey 
et al. 1980). When nitrite is present, the ultimate level of methaemoglobin in the blood is a result of the balance between methaemoglobin formation and conversion to haemoglobin by methaemoglobin reductase (Lew is and Morris 1986). As fish are poikilotherms, the reductase enzyme varies in efficiency with seasonal temperatures (Perrone and Meade 1977) and its activity is possibly accelerated by enhanced temperature.

Nitrite-exposed fish showed lower haematocrit values (PCV) at both experimental temperatures compared with controls. Haematocrit is based on both erythrocyte count $(\mathrm{RBC})$ and volume (MCV). Either low RBC or low MCV caused a decrease of haematocrit values in dependence on water temperature. At the higher temperature, a decrease in PCV accompanied by a decrease in RBC and in the haemoglobin concentration $(\mathrm{Hb})$, in addition to the constant MCV, can be possibly attributed to blood cell lysis. Since the high activity of the methaemoglobin-reductase system to convert the methaemoglobin to haemoglobin during nitrite exposure results in a high metabolic cost to the red blood cells, the normal life span of these cells is shortened ( $\mathrm{Scarano}$ et al. 1984). The activity of the methaemoglobinreductase system was probably enhanced by the higher temperature as mentioned above. In contrast, at the lower temperature, PCV and MCV decreased, and RBC with $\mathrm{Hb}$ concentration remained unchanged. In this case, a decrease in PCV is possibly caused by red cell shrinkage as reported by Jensen et al. (1987). The RBC shrinkage is connected with the efflux of $\mathrm{K}^{+}$from the red blood cells. The $\mathrm{K}^{+}$efflux seems to result from activation of $\mathrm{a} \mathrm{K}^{+} / \mathrm{Cl}^{-}$cotransporter that is normally involved in cell volume regulation (Jensen 1990). The activation of $\mathrm{K}^{+} / \mathrm{Cl}^{-}$efflux draws osmotically obligated water out of the cells and hence induces erythrocyte shrinkage (Jensen 1990). However, this hypothesis is not supported by an increase of mean corpuscular haemoglobin concentration (MCHC), which may be elevated by erythrocyte shrinkage. We did not notice any significant differences in selected erythrocyte proportions.

In carp, plasma osmolality was constant at both experimental temperatures. However, certain alteration in the plasma electrolyte status occurred. Nitrite poisoning caused a marked increase in plasma potassium concentrations in both test groups compared with controls. The divergence between groups C1 - E1 and C2 - E2 reached nearly the same percentage value. Jen sen et al. (1987) originally observed that nitrite-induced extracellular hyperkalaemia in carp. The rise in plasma $\mathrm{K}^{+}$is due to the nitrite stimulated release of $\mathrm{K}^{+}$ from skeletal muscle and red blood cells (Jensen 1990; Knudsen and Jensen 1997). In accordance with the findings of Jensen et al. (1987), we found that plasma $\mathrm{Na}^{+}$ concentrations slightly decreased in group E2 $\left(20^{\circ} \mathrm{C}\right)$. However, in group E1 $\left(14{ }^{\circ} \mathrm{C}\right)$, the values remained unchanged. We also observed that water temperature itself suggested an influence on plasma $\mathrm{K}^{+}$and $\mathrm{Na}^{+}$levels (significant difference between control group $\mathrm{C} 1$ and C2). Our data confirm the results of Metz et al. (2003), who showed that raising temperature induces a decrease in plasma $\mathrm{K}^{+}$and $\mathrm{Na}^{+}$levels. Plasma $\mathrm{Cl}^{-}$levels were not affected by nitrite poisoning in either of the experimental groups, which is in contrast with the results of several authors (Jensen et al. 1987; Knudsen and Jensen 1997). Nitrite is a competitive inhibitor of chloride uptake and vice versa (Williams and Eddy 1986); thus, chloride influx is reduced due to the presence of nitrite in ambient water. On the other hand, in fish exposed to nitrite, there is a concomitant loss of $\mathrm{K}^{+}$and $\mathrm{Cl}^{-}$from skeletal musculature (Knudsen and Jensen 1997). Thus, chloride levels remained unchanged, possibly due to the interaction of the above-mentioned effects.

In conclusion, our experiment indicates that mortality and methaemoglobinaemia during nitrite poisoning are not related to water temperature. However, other haematological and biochemical variables $\left(\mathrm{NO}_{2}^{-}\right.$in the blood plasma, muscle, and liver; plasma $\mathrm{Na}^{+}$ concentration; $\mathrm{Hb}$; PCV; RBC) were more altered during nitrite exposure at higher temperature. 


\section{Otrava kapra obecného (Cyprinus carpio L.) dusitany při různých teplotách}

Dvě skupiny kaprů obecných (Cyprinus carpio L.) byly po dobu 48 hodin vystaveny zvýšené koncentraci dusitanů $\left(1,45 \mathrm{mmol} \cdot \mathrm{l}^{-1} \mathrm{NO}_{2}^{-}\right)$při dvou různých teplotách $\left(14^{\circ} \mathrm{C}\right.$ 1. skupina a $20^{\circ} \mathrm{C}-2$. skupina). Vliv zvýšené koncentrace dusitanů na ryby při různých teplotách byl hodnocen pomocí vybraných hematologických a biochemických ukazatelů krve ryb. Navíc byla stanovena koncentrace dusitanů v krvi, játrech a svalovině. Po působení dusitanů došlo při obou teplotách ke zvýšení hladiny methaemoglobinu $(88,2 \pm 3,3 \%$ a $92,9 \pm 6,1 \%)$ v krvi ryb v porovnání s kontrolními skupinami $(0,3 \pm 0,6 \%$ a 2,6 $\pm 3,0 \%)$. V obou experimentálních skupinách byla navíc zaznamenána vysoká mortalita ryb (30\% a 51\%). Dusitany byly kumulovány v těle ryb. Nejvyšší koncentrace byly naměřeny $\mathrm{v}$ krevní plasmě, nižší $\mathrm{v}$ játrech a svalovině ryb, přičemž statisticky významně souvisely s teplotou vody. Při $20{ }^{\circ} \mathrm{C}$ dosáhla koncentrace dusitanů v plasmě pokusných ryb hodnoty $10,5 \pm 1,9 \mathrm{mmol} \cdot \mathrm{l}^{-1}$, což je 7 krát více než v okolní vodě. Při $14{ }^{\circ} \mathrm{C}$ byly naměřeny signifikantně nižší hodnoty $\left(5,0 \pm 1,5 \mathrm{mmol} \cdot \mathrm{l}^{-1}\right)$. Expozice ryb dusitanům dále vyvolala $\mathrm{v}$ obou případech zvýšení koncentrace draslíku v krevní plasmě, naproti tomu koncentrace chloridů a osmolalita plasmy zůstaly nezměněny. Při vyšší teplotě došlo v plasmě ryb k poklesu obsahu sodíku. Přri obou teplotách bylo u pokusných ryb zjištěno snížení hematokritové hodnoty. Při teplotě vody $20{ }^{\circ} \mathrm{C}$ byla nízká hodnota hematokritu $\left(0,20 \pm 0,021.1^{-1}\right)$ doprovázena sníženým počtem erytrocytů $\left(1,05 \pm 0,12.10^{12}\right.$ $\left.\mathrm{l}^{-1}\right)$ a sníženou koncentrací hemoglobinu $\left(51 \pm 11 \mathrm{~g} \cdot \mathrm{l}^{-1}\right)$ v porovnání s kontrolou. Při nižší teplotě $\left(14{ }^{\circ} \mathrm{C}\right)$ byl pokles hematokritu $\left(0,25 \pm 0,021 \cdot 1^{-1}\right)$ doprovázen nízkými hodnotami střredního objemu erytrocytu $(167 \pm 27$ fl). Působení dusitanů na ryby naopak nevyvolalo při žádné z teplot změny v hodnotách hemoglobin erytrocytu, střední barevné koncentrace ani rozměrů nativních červených krvinek proměřovaných v horizontální rovině jako hlavní a vedlejší osy elipsy.

\section{Acknowledgements}

This study was supported by research plan of the University of South Bohemia České Budějovice, Research Institute of Fish Culture and Hydrobiology (USB RIFCH) No. MSM6007665809.

\section{References}

BODANSKY O 1951: Methaemoglobinemia and methaemoglobin-producing compounds. Pharmacol Rev 3: $144-196$

CAIRNS J Jr, HEATH AG, PARKER BC 1975: The effect of temperature upon the toxicity of chemicals to aquatic organisms. Hydrobiologia 47: 135-171

CAMERON JN 1971: Methaemoglobin in erythrocytes of rainbow trout. Comp Biochem Physiol A 40: 743-749

COLT J, TCHOBANOGLOUS G 1976: Evaluation of short-term toxicity of nitrogenous compounds in the channel catfish, Ictalurus punctatus. Aquaculture 8: 209-224

CRAWFORD RE, ALLEN GH 1977: Seawater inhibition of nitrite toxicity to chinook salmon. Trans Amer Fish Soc 106: $105-109$

GISBERT E, RODRÍGUEZ A, CARDONA L, HUERTAS M, GALLARDO MA, SARASQUETE C, SALARABANAL M, IBARZ A, SÁNCHEZ J, CASTELLÓ-ORVAY F 2004: Recovery of Siberian sturgeon yearlings after an acute exposure to environmental nitrite: changes in the plasmatic ionic balance, $\mathrm{Na}^{+}-\mathrm{K}^{+}$ ATPase activity, and gill histology. Aquaculture 239 (1-4): 141-154

HUEY DW, BEITINGER TL, WOOTEN MC 1984: Nitrite-induced methaemoglobin formation and recovery in channel catfish (Ictalurus punctatus) at three acclimation temperatures. Bull Environ Contam Toxicol 32: 674-681

HUEY DW, SIMCO BA, CRISWELL DW 1980: Nitrite-induced methaemoglobin formation in channel catfish. Trans Amer Fish Soc 109: 558-562

JEBERG MV, JENSEN FB 1994: Extracellular and intracellular ionic changes in crayfish Astacus astacus exposed to nitrite at two acclimation temperatures. Aquat Toxicol 29: 65-72

JENSEN FB 1990: Nitrite and red cell function in carp: control factors for nitrite entry, membrane potassium ion permeation, oxygen affinity and methaemoglobin formation. J Exp Biol 152: 149-166

JENSEN FB 2003: Nitrite disrupts multiple physiological functions in aquatic animals. Comp Biochem Physiol A 135: 9- 24 
JENSEN FB, ANDERSEN NA, HEISLER N 1987: Effects of nitrite exposure on blood respiratory properties, acid - base and electrolyte regulation in the carp (Cyprinus carpio). J Comp Physiol B 157: 533-541

KAMSTRA A, SPAN JA, VAN WEERD JH 1996: The acute toxicity and sublethal effects of nitrite on growth and feed utilization of European eel, Anguilla anguilla (L.). Aquac Res 27: 903-911

KNUDSEN PK, JENSEN FB 1997: Recovery from nitrite-induced methaemoglobinaemia and potassium balance disturbances in carp. Fish Physiol Biochem 16: 1-10

LEWIS WM, MORRIS DP 1986: Toxicity of nitrite to fish: A Review. Trans Amer Fish Soc 115: 183-195

MÁCHOVÁ J, SVOBODOVÁ Z 2001: Nitrite toxicity for fish under experimental and farming conditions. In: 10th International conference of the EAFP Diseases of Fish and Shellfish, Dublin, 9th - 14th September 2001, p. 275.

MARGIOCCO C, ARILLO A, MENSI P, SHENONE G 1983: Nitrite bioaccumulation in Salmo gairdneri Rich. and haematological consequences. Aquat Toxicol 3: 261-270

METZ JR, VAN DEN BURG EH, WENDELAAR BONGA SE, FLIK G 2003: Regulation of branchial Na ${ }^{+} / \mathrm{K}^{+}-$ ATPase in common carp Cyprinus carpio L. acclimated to different temperatures. J Exp Biol 206 : $2273-2280$

PERRONE SJ, MEADE TL 1977: Protective effect of chloride on nitrite toxicity to coho salmon (Oncorhynchus kisutch). J Fish Res Board Can 34: 486-492

PIŠTĚKOVÁ V, VOSLÁŘOVÁ E, SVOBODOVÁ Z 2005: Nitrite toxicity to Danio rerio: effect of chloride concentration during acclimation and in toxicity tests. Acta Vet Brno 74: 435-440

SCARANO G, SAROGLIA MG, GRAY RH, TIBALI E 1984: Haematological responses of sea bass Dicentrarchus labrax to sublethal nitrite exposures. Trans Amer Fish Soc 113: 360-364

SCHMIDT H, POSTHAUS H, BUSATO A, WAHLI T, MEIER W, BURKHARDT- HOLM P 1998: Transient increase in chloride cell number and heat shock protein expression (Hsp70) in brown trout (Salmo trutta fario) exposed to sudden temperature elevation. Biol Chem 379 (10): 1227-1233

SHECHTER H, GRUENER N, SHUBAL HI 1972: Micromethod for the determination of nitrite in blood. Anal Chim Acta 60: 93-99

SVOBODOVÁ Z, MÁCHOVÁ J, POLESZCZUK G, HŮDA J, HAMÁČKOVÁ J, KROUPOVÁ H 2005a: Nitrite poisoning of fish in aquaculture facilities with water-recirculating systems: three Case Studies. Acta Vet Brno 74: $129-137$

SVOBODOVÁ Z, PRAVDA D, PALÁČKOVÁ J 1991: Unified methods of haematological examination of fish. Methods No. 20, Research Institute of Fish Culture and Hydrobiology, Vodnany, Czech Republic, 31 p.

SVOBODOVÁ Z, MÁCHOVÁ J, DRASTICHOVÁ J, GROCH L, LUSKOVÁ V, POLESZCZUK G, VELÍŠEK J, KROUPOVÁ H. 2005b: Haematological and biochemical profile of carp blood following nitrite exposure at different concentration of chloride. Aquac Res 36(12): 1177- 1184

WILLIAMS EM, EDDY FB 1986: Chloride uptake in freshwater teleosts and its relationship to nitrite uptake and toxicity. J Comp Physiol B 156: 867-872

WOOD CM 1993: Ammonia and urea metabolism and excretion. In: EWANS DH (Ed.): Physiology of Fishes, CRC Press Boca Raton, pp. 379-425

ZAR JH 1996: Biostatistical Analysis, 3rd ed, Prentice-Hall, New Jersey, 718 p. 